\title{
Short communication: An evaluation of the effectiveness of Lactobacillus buchneri 40788 to alter fermentation and improve the aerobic stability of corn silage in farm silos
}

\author{
L. J. Mari, ${ }^{\star} †$ R. J. Schmidt, ${ }^{*}$ L. G. Nussio,† C. M. Hallada, $\ddagger$ and L. Kung Jr. ${ }^{* 1}$ \\ *University of Delaware, Newark 19716-2150 \\ +University of Sao Paulo, Piracicaba, Sao Paulo 1318-900, Brazil \\ ¥Vita Plus Corporation, Madison, WI 53713
}

\begin{abstract}
The objective of this study was to determine if the effects of inoculation with Lactobacillus buchneri 40788 were detectable when applied to whole-plant corn stored in farm silos. Corn silage was randomly sampled from farms in Wisconsin, Minnesota, and Pennsylvania, and was untreated $(\mathrm{n}=15)$ or treated with an inoculant (n = 16) containing L. buchneri 40788 alone or this organism combined with Pediococcus pentosaceus during May and June 2007. Corn silage that was removed from the silo face during the morning feeding was sampled, vacuum-packed, and heat sealed in polyethylene bags and shipped immediately to the University of Delaware for analyses. Silage samples were analyzed for dry matter (DM), nutrient composition, fermentation endproducts, aerobic stability, and microbial populations. The population of L. buchneri in silages was determined using a real-time quantitative PCR method. Aerobic stability was measured as the time after exposure to air that it took for a $2^{\circ} \mathrm{C}$ increase above an ambient temperature. The DM and concentrations of lactic and acetic acids were 35.6 and $34.5,4.17$ and 4.85 , and 2.24 and $2.41 \%$, respectively, for untreated and inoculated silages and were not different between treatments. The concentration of 1,2-propanediol was greater in inoculated silages (1.26 vs. $0.29 \%$ ). Numbers of lactic acid bacteria determined on selective agar were not different between treatments. However, the numbers of L. buchneri based on measurements using real-time quantitative PCR analysis were greater and averaged $6.46 \mathrm{log}$ cfu-equivalents/g compared with $4.89 \mathrm{log}$ cfu-equivalent for inoculated silages. There were fewer yeasts and aerobic stability was greater in inoculated silages (4.75 $\log \mathrm{cfu} / \mathrm{g}$ and $74 \mathrm{~h}$ of stability) than in untreated silages ( $5.55 \mathrm{log} \mathrm{cfu} / \mathrm{g}$ and $46 \mathrm{~h}$ of stability).
\end{abstract}

Received September 10, 2008.

Accepted November 13, 2008.

${ }^{1}$ Corresponding author: lksilage@udel.edu
This study supports the effectiveness of L. buchneri 40788 on dairy farms.

Key words: silage, Lactobacillus buchneri, spoilage

Lactobacillus buchneri was introduced into the US silage market in 2002. Since then, many studies have documented its effects of increasing acetic acid and reducing the numbers of yeasts and molds, thus improving aerobic stability (Kleinschmit and Kung, 2006a). However, most of these studies were conducted in laboratory-scale silos and some researchers have questioned the suitability of these silos to predict results in farm-scale silos. Thus, it was the objective of this study to determine if the effects of inoculation with $L$. buchneri 40788 were detectable when applied to wholeplant corn stored in farm silos.

Corn silage samples were collected from dairy farms in Wisconsin, Pennsylvania, and Minnesota during May and June 2007. Fifteen samples were collected from farms that did not inoculate their silages (untreated). Sixteen samples were obtained from farms that applied either L. buchneri 40788 (to achieve a final application rate of $4 \times 10^{5} \mathrm{cfu} / \mathrm{g}$ of fresh forage) alone or $L$. buchneri $40788\left(4 \times 10^{5} \mathrm{cfu} / \mathrm{g}\right.$ of fresh forage) combined with Pediococcus pentosaceus (to achieve a final application rate of $1 \times 10^{5} \mathrm{cfu} / \mathrm{g}$ of fresh forage) at the time of ensiling. The inoculants were products of Lallemand Animal Nutrition (Milwaukee, WI) and distributed by Vita Plus Corporation (Madison, WI). All silages except for 1 sample were harvested and ensiled in the fall of the previous year. Untreated silages were sampled from 9 bunker silos, 4 bag silos, and 2 pile silos, whereas inoculated silages were sampled from 8 bunker silos, 5 bag silos, and 3 pile silos.

Representative samples of silages were collected from the morning removal of silage from the silos and vacuumpacked and heat-sealed in polyethylene bags. Samples were shipped for next-day delivery to the University of Delaware (Newark) for analysis. Upon arrival, samples were immediately processed. Subsamples (about $300 \mathrm{~g}$ ) of each silage were placed in $350-\mathrm{mL}$ polystyrene cups 
Table 1. Nutrient composition (DM basis) of untreated or treated corn silages collected from farm silos

\begin{tabular}{lcccc}
\hline Item & Untreated & Lactobacillus buchneri 40788 & SEM & $P$-value \\
\hline $\mathrm{DM}, \%$ & 35.6 & 34.5 & 1.0 & 0.4 \\
$\mathrm{CP}, \%$ & 8.27 & 8.63 & 0.28 & 0.36 \\
$\mathrm{NH}_{3}-\mathrm{N}, \%$ & 0.09 & 0.11 & 0.13 \\
$\mathrm{NDF}, \%$ & 38.15 & 0.95 & 0.49 \\
$\mathrm{ADF}, \%$ & 39.08 & 21.80 & 0.71 & 0.44 \\
\hline
\end{tabular}

surrounded by insulation. Those samples were used to determine aerobic stability by placing a thermocouple wire in the geometric center of the silage mass and exposing the silage to air in a room at $23 \pm 1^{\circ} \mathrm{C}$. Aerobic stability was measured as the time after exposure to air that it took for the temperature of the silage mass to increase $2^{\circ} \mathrm{C}$ above the ambient temperature.

Subsamples of silages were placed in forced-air oven $\left(60^{\circ} \mathrm{C}\right)$ for $48 \mathrm{~h}$ to determine the DM content. Dried samples were analyzed for total $\mathrm{N}$ by using a Leco CNS 2000 Analyzer (Leco Corp., St. Joseph, MI). The NDF and ADF contents were analyzed in an Ankom Fiber Analyzer (Ankom Technology Corp., Fairport, NY), using the Van Soest et al. (1991) method, adapted by Holden (1999).

Water extracts were prepared from the received silage samples, and fermentation end-products were analyzed as described by Kleinschmit and Kung (2006b). The numbers of viable lactic acid bacteria were determined by pour plating 10 -fold serial dilutions of silage water extracts on de Man, Rogosa, and Sharpe agar (CM3651, Oxoid, Basingstoke, UK). Plates were incubated anaerobically at $32^{\circ} \mathrm{C}$ for 48 to $72 \mathrm{~h}$. Yeasts and molds were determined by pour plating 10 -fold serial dilutions in malt extract agar (CM59, Oxoid) that had been acidified, after autoclaving, by the addition of $85 \%$ lactic acid (AC12506-5000, Fisher Scientific, Pittsburgh, $\mathrm{PA})$ at a concentration of $0.5 \%$ ( $\mathrm{vol} / \mathrm{vol})$. Plates were incubated aerobically at $32^{\circ} \mathrm{C}$ for 48 to $72 \mathrm{~h}$. Numbers of Lactobacillus buchneri (cfu-equivalent, cfu-e) were determined using a real-time quantitative PCR method (Schmidt et al., 2008). Numbers of L. buchneri are presented as cfu-equivalents because detected bacterial DNA can come from viable and dead bacteria. The study was a completely randomized design analyzed by
PROC GLM (SAS Institute, 2002). Significance was declared when $P \leq 0.05$.

The nutrient contents of untreated and inoculated silages are shown in Table 1 and were not different between treatments. The microbial populations of corn silages are shown in Table 2. Numbers of viable lactic acid bacteria determined on selective agar were similar between treatments. Untreated corn silage contained $4.89 \mathrm{log}$ cfu-e/g of L. buchneri. Because the PCR technique does not differentiate among strains of $L$. buchneri, these data showed naturally occurring $L$. buchneri developed in the untreated silages (almost $10^{5} \mathrm{cfu}-\mathrm{e} / \mathrm{g}$ ). However, when corn silage was treated with inoculants containing a select strain of L. buchneri (40788), it established a markedly higher population (6.46 log cfu$\mathrm{e} / \mathrm{g})$. The number of yeasts in treated silage tended $(P$ $<0.10)$ to be lower in inoculated silages, which supports data from past studies (Kleinschmit and Kung, 2006a). Molds were low even in untreated corn silage but were undetectable in inoculated silage.

The concentrations of lactic and acetic acids were numerically greater in inoculated than in untreated silages (Table 3). Concentrations of propionic acid and butyric acid were low and not different between treatments. The concentration of ethanol was also similar between treatments. Lack of a statistical difference in the concentration of acetic acid (a hallmark of silages treated with $L$. buchneri) between untreated and inoculated silages might have been due to the fact that silage samples were collected from active feeding faces of silos and in general had been exposed to air for an entire evening. This may have resulted in some volatilization of acids, and aerobic metabolism of yeasts may have already begun. Another explanation for this finding may be that air can penetrate 1 to $2 \mathrm{~m}$ into the ac-

Table 2. Microbial populations (wet basis) of untreated or treated corn silages collected from farm silos

\begin{tabular}{lccrr}
\hline Item & Untreated & L. buchneri 40788 & SEM & P-value \\
\hline $\mathrm{LAB},{ }^{1} \log \mathrm{cfu} / \mathrm{g}$ & 6.02 & 6.52 & 0.31 & 0.25 \\
Lactobacillus buchneri, log cfu-e/g & & 6.46 & 0.44 & $<0.02$ \\
Yeasts, $\log \mathrm{cfu} / \mathrm{g}$ & 4.89 & 4.75 & 0.34 & 0.10 \\
Molds, log cfu/g & 5.55 & 0.00 & 0.35 & $<0.05$ \\
\hline
\end{tabular}

${ }^{1}$ Viable and culturable lactic acid bacteria determined on De Man, Rogosa, and Sharpe agar.

${ }^{2}$ Colony forming unit-equivalent of L. buchneri determined by real-time quantitative PCR. 
Table 3. The $\mathrm{pH}$, fermentation end-products (DM basis), and aerobic stability of untreated or treated corn silages collected from farm silos

\begin{tabular}{lcccc}
\hline Item & Untreated & $\begin{array}{c}\text { Lactobacillus } \\
\text { buchneri 40788 }\end{array}$ & SEM & $P$-value \\
\hline $\mathrm{pH}$ & 3.71 & 3.67 & 0.35 & 0.43 \\
Lactic acid, \% & 4.17 & 4.85 & 0.42 & 0.25 \\
Acetic acid, \% & 2.24 & 2.41 & 0.37 & 0.74 \\
Propionic acid, \% & 0.24 & 0.20 & 0.10 & 0.76 \\
Butyric acid, \% & 0.04 & 0.02 & 0.03 & 0.72 \\
1,2-propanediol, \% & 0.29 & 1.26 & 0.20 & $<0.01$ \\
Ethanol, \% of DM & 0.70 & 0.69 & 0.15 & 0.97 \\
Aerobic stability, ${ }^{1} \mathrm{~h}$ & 46 & 76 & 8 & 0.02 \\
\hline
\end{tabular}

${ }^{1}$ The number of hours until a $2^{\circ} \mathrm{C}$ increase in the temperature of the silage mass after exposure to air in a room at $23 \pm 1^{\circ} \mathrm{C}$.

tive feeding face of a silo. Under these conditions, some lactic acid bacteria are able to produce both lactic and acetic acids (Pahlow et al., 2003). However, in the current study, greater concentrations of 1,2-propanediol in inoculated compared with untreated silage was further evidence that the anaerobic conversion of lactic acid to acetic acid was active in inoculated silages as this compound is another major end-product from the anaerobic conversion of lactic acid to acetic acid by L. buchneri (Oude Elferink et al., 2001). The desired effect from treating silages with $L$. buchneri is improved aerobic stability, and this was higher in silages inoculated with this organism, most likely as a direct effect of suppressing the growth of yeasts in silage.

To our knowledge, this is the first study that has proven the wide-scale efficacy of a commercial silage inoculant in farm silos by determining the population of the added organism using molecular techniques. In conclusion, these findings show that treating silages with L. buchneri 40788 is an effective means of preserving and improving the aerobic stability of silages and the effects of the inoculant can be measured in on-farm silos.

\section{ACKNOWLEDGMENTS}

This research was partially supported by Lallemand Animal Nutrition (Milwaukee, WI). The authors thank the field staff of Vita Plus Corporation (Madison, WI) for assistance with sample collection.

\section{REFERENCES}

Holden, L. A. 1999. Comparison of methods of in vitro dry matter digestibility for ten feeds. J. Dairy Sci. 82:1791-1794.

Kleinschmit, D. H., and L. Kung Jr. 2006a. A meta-analysis of the effects of Lactobacillus buchneri on the fermentation and aerobic stability of corn, grass and small grain silages. J. Dairy Sci. 89:4005-4013.

Kleinschmit, D. H., and L. Kung Jr. 2006b. The effects of Lactobacillus buchneri 40788 and pediococcus pentosaceus R1094 on the fermentation of corn silage during various stages of ensiling. J. Dairy Sci. 89:3999-4004.

Oude Elferink, S. J. W. H., J. Krooneman, J. C. Gottschal, S. F. Spoelstra, F. Faber, and F. Driehuis. 2001. Anaerobic conversion of lactic acid to acetic acid and 1,2-propanediol by Lactobacillus buchneri. Appl. Environ. Microbiol. 67:125-132.

Pahlow, G., R. E. Muck, F. Driehuis, S. J. W. H. Oude-Elferink, and S. F. Spoelstra. 2003. Microbiology of Ensiling. Pages 31-93 in Silage Science and Technology. D. R. Buxton, R. E. Muck, and J. H. Harrison, ed. American Society of Agronomy, Madison, WI.

SAS Institute. 2002. The SAS System for Windows: Version 9.00. Cary, NC.

Schmidt, R. J., M. G. Emara, and L. Kung Jr. 2008. The use of a quantitative real-time polymerase chain reaction assay for identification and enumeration of Lactobacillus buchneri in silages. J. Appl. Microbiol. 105:920-929.

Van Soest, P. J., J. B. Robertson, and B. A. Lewis. 1991. Methods for dietary fiber, neutral detergent fiber, and nonstarch polysaccharides in relation to animal nutrition. J. Dairy Sci. 74:3583-3597. 